\title{
THE CONTINENTAL SHELF
}

$\mathrm{O}$ NE morning of the British Association meeting at Liverpool was devoted to a joint discussion by Sections C (Geology), D (Zoology) and E (Geography) on problems of the continental shelf. First, Dr. L. H. N. Cooper, of the Marine Biological Laboratory, Plymouth, developed a hypothesis to explain the fluctuations in biological productivity of the English Channel in terms of climatic conditions in the Arctic. During the 1920's the Channel contained about $0.7 \mu \mathrm{gm}$.-atom/litre phosphate as measured at the winter maximum, and there occurred an abundant macroplankton characterized by several biological indicators, including Sagitta elegans. About 1930 the winter maximum of phosphate fell and settled down at about $0.45 \mathrm{\mu gm}$.-atom/litre. This was accompanied by a marked decrease in abundance of macroplankton and a change in the indicator species, $S$. setosa replacing $S$. elegans. Herrings also became less abundant, and after 1934 the Plymouth commercial herring fishery was completely extinguished. Evidence for a complementary earlier enrichment is incomplete; but there is some evidence for it shortly before the nutrient studies started in 1923. An explanation is likely to be in terms of an event that occurs only a few times in a century.

During the years 1947-50 the search for an explanation was extended to the Celtic Sea, south and west of the Scillies. Waters were found of elegans type and richer in phosphate than those near Plymouth; but none was as rich as that in the Channel during the 1920's. Within this area there is not a single clue which would suggest to-day a physical regime fundamentally different from that of thirty years ago. Since, whatever the ultimate cause may be, it is not local, the search has to be extended to the Atlantic Ocean.

Upwelling due to off-shore or off-slope winds is one possibility. However, during six weeks covering the notorious February of 1947, easterly winds were strong enough and lasted long enough to bring about upwelling of deeper water, but no enrichment ensued. Work later on R.R.S. Discovery II showed that to-day in the neighbouring Atlantic adequate nutrient resources are not within reach of any physical forces which could bring them to the surface. To make this possible, the nutrient table containing $0 \cdot 8 \mu \mathrm{gm}$.-atom/ litre would need to be raised by about $400 \mathrm{~m}$. The conclusion seems inescapable that thirty years ago this nutrient table must indeed have lain $400 \mathrm{~m}$. higher in the water than it does to-day and that it had been raised by upward displacement by an equal volume of water intruded at a greater depth, perhaps at the very bottom of the Atlantic. Abyssal water is always cold, having sunk from the surface in winter in high latitudes. It was concluded that much polar water must have sunk in the years before 1921 and that relatively little is sinking now.

Two events are necessary for the production of deep water in high latitudes: the presence of water of sufficiently high salinity; and air temperatures low enough to cool this saline water sufficiently for it to become the heaviest water in the North Atlantic. A principal northern area where this may occur is around southern Greenland. A series of cold winters there during the first twenty years of this century culminated in three very harsh winters in 1918,1920 and 1921, during which time much deep Atlantic water must have been formed, leading to upward displacement of the overlying water. Nothing comparable has been experienced since, so that upward displacement and resulting nutrient enrichment of surface waters should have become much reduced.

It is suspected that this conclusion has emerged first from work on the English Channel because this has mostly a rock or sand bottom. Due to its strong tidal currents, there is little local deposition of organic mud or ooze. In regions of weaker tides, during years of rich production a capital reserve of organic mud is thought to be laid down and then by slow decomposition to yield dividends of nutrients and growth-promoting substances for many years afterwards. Thus, in such places, the failure to recruit fresh supplies of nutrients derived from oceanic upward displacement may be masked.

In the discussion, Dr. R. E. Craig, of the Scottish Home Department Marine Laboratory, Aberdeen, strongly supported the policy of looking at major climatic changes as first causes of observed hydrographical and plankton changes, but felt that the hypothesis merely presents a mechanism for increasing the thermal circulation and cannot necessarily be expected to raise the level of any of the horizontal boundaries in the sea. He also felt that 1921 was in every way an exceptional year able to produce the observed changes by the means which he outlined.

The Bear Island Shelf was the subject of a paper by Mr. Michael Graham and Mr. A. J. Lee, of the Fisheries Laboratory, Lowestoft. It lies between Norway and Spitsbergen, receiving from the northeastwards a cold current against which two branches of warm, more saline Atlantic water impinge: the West Spitsbergen and the North Cape currents. As it is the site of the greatest single British fishery, conditions over it have been extensively studied by the fisheries research vessel Ernest Holt. The success of the fishery is found much to depend on where and to what extent Atlantic water of temperature $2-4^{\circ} \mathrm{C}$. touches the sea bed. In March 1949 west of Bear Island such water extended from a depth on the shelf of about $150 \mathrm{~m}$. to beyond the trawlable limit of $500 \mathrm{~m}$. There was no ice about. On the same date in 1950 there was ice extending 30 miles west of the island, and no water warmer than $2^{\circ} \mathrm{C}$. was found above $220 \mathrm{~m}$.- - that is, $70 \mathrm{~m}$. deeper and about nine miles nearer the edge of the shelf. The breadth of the trawlable zone had become less than ten miles.

In 1949 much saline Atlantic water was present, having been blown there by preceding south-easterly winds. The presence of such saline water favours the formation of homogeneous water and hampers the development of surface ice. The distribution of density showed that the shelf waters west of Bear Island had become heavy enough to cascade over the edge and down the continental slope. In Mr. Lee's opinion, cascading down the slope of the shelf is an essential part of the mechanism thought to govern this spring fishery. "The conditions of the fishery during the rest of the year were also described.

The title of the last paper, "Territorial Problems associated with the Continental Shelf", whetted 
curiosity since few of the audience realized that there were any. Dr. A. E. Moodie, a geographer of Birkbeck College, London, presented to zoologists and geologists an account of the evolution of international law relating to the sovereignty of coastal States over the continental shelf. Though the implications were clear enough, the story seemed as unreal as that of a comic opera and could have no place in a discussion on natural science. [See also p. 1063 of this issue of Nature.]

Since 1939, and especially since 1945, there has been a spate of claims to exercise sovereignty over the shelf, especially by American Republics. The United Kingdom has been party with Venezuela to a division of the Gulf of Paria. Motives have been twofold: the search for oil and the attainment of security. Many unilateral claims have been extravagant, and the legal position was becoming chaotic. In 1948, therefore, the General Assembly of the United Nations recommended to the International Law Commission that it should give priority to discussions on the regime of the high seas. After five years of argument and counter-argument, the Commission has agreed to recognize in principle qualified sovereign rights of a coastal State over the adjacent part of the shelf. It does not follow that the General Assembly will accept them.

The latest information available to Dr. Moodie was United Nations Press Release L/47, dated July
17, 1953, while the jurists were still sitting. The draft articles in full with an extended commentary were published on August 17 as United Nations General Assembly $A / C N .4 / 76$, pp. 35-56. This document shows that the Commission recommends that all contiguous waters shall be divided into two zones : the territorial sea, broadly equivalent to the present concept of territorial waters extending from the coast for three or some other number of miles to seaward; and the continental shelf, extending from the limit of the territorial sea to a depth of $200 \mathrm{~m}$. The major difference in legal status will be that within the territorial sea the coastal State exercises, as previously, complete sovereignty over sea-floor, subsoil and superjacent waters, whereas over the continental shelf the superjacent waters and airspace will not be subject to the sovereignty of the coastal State. Over the whole of the continental shelf the coastal State will exercise sovereignty over the exploration and exploitation of the sea-bed and subsoil, just as it does over its land territory. The extension of the seaward boundaries of a coastal State to the $200-\mathrm{m}$. contour means a very great extension of the State's authority and could in some circumstances become a grave hindrance not only to trade and fishing but also to scientific research. Juridical problems, affecting the freedom of marine research, may arise when two or more States lie adjacent to the same continental shelf.

\section{INTERNATIONAL PHYSIOLOGICAL CONGRESS, MONTREAL}

$\mathrm{T}$ HE XIX International Physiological Congress was opened in the Sir Arthur Currie gymnasium of McGill University, Montreal, on Monday, August 31 , 1953, at 5 p.m., by the president, Prof. C. H. Best, of the University of Toronto. The platform party made an imposing entry to the large gym. nasium filled with more than two thousand members of the Congress, who stood in respect as their senior colleagues, together with the dignitaries of Montreal and of Quebec Province, passed along the centre aisle. This impressive stage-management was characteristic of the superb efficiency with which the local organizing committee, ably led-and perhaps driven - by Prof. F. C. MacIntosh, of McGill University, had organized the whole of this vast Congress.

Following the official opening of the Congress, the remainder of this plenary session consisted of speeches of welcome from Dr. J. B. Collip, president of the Canadian Physiological Society, which was the host organization to the Congress; from Dr. F. C. James, principal of McGill University, on behalf both of MeGill University and of the University of Montreal ; from Mayor Camillien Houde, on behalf of the city of Montreal ; and from Dr. G. D. W. Cameron, deputy minister of health, on behalf of the Government of Quebec. The president of the Congress conveyed the thanks of all members to the many host organizations, in a large variety of languages, including Iroquois; in fact, the linguistic attainments of the platform party were astonishing, from Dr. Collip's speech in French, onwards; but the thunder of the whole session was stolen by Mayor Houde, whose memorable address made even vital statistics vital. Shortly before the close of the meeting, Dr. E. D. Adrian, of the University of Cambridge, outlined the plan of the Permanent Committee, of which he is president, for the establishment of an International Union of Physiological Sciences, and promised members that the Permanent Committee at least intended to work during the Congress-and hoped to present the final recommendations at the closing plenary session. The entire concourse then made its way very slowly up a steep hill to Forbes Field, where, in the open air, all were entertained at the hands of the Provincial Government of Quebec. This reception was memorable, not only for being held in such pleasant surroundings, not only for the unrivalled opportunities for meeting, for the first time, many of one's fellow members, not only for the generous spirit of the Government of Quebec, but also for a buffet which broke all records in running out of soft drinks and sodawater only. In this way then did August fade away, and on the first of September members were faced with a staggering programme of scientific sessions, and the technical work of the Congress began.

It is said in North America that only the English can talk uninterruptedly for longer than thirty seconds about the weather; but all racial records were broken in Montreal, where, despite the unparalleled opportunities for 'shop', the climate must surely have taken pride of place as a subject for discussion. The Congress basked or baked in temperatures that seldom-or was it ever?--fell out of the 90 's, and members were little comforted by the repeated assurances of the 'locals' that this was most unusual for the time of the year. Recollection of sessions in hot and crowded lecture halls will remain long after memory of the scientific proceedings has faded; but more comfortable recol- 